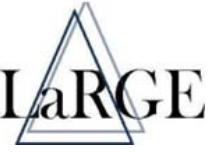

\title{
Laboratoire
} de Recherche en Gestion \& Economie

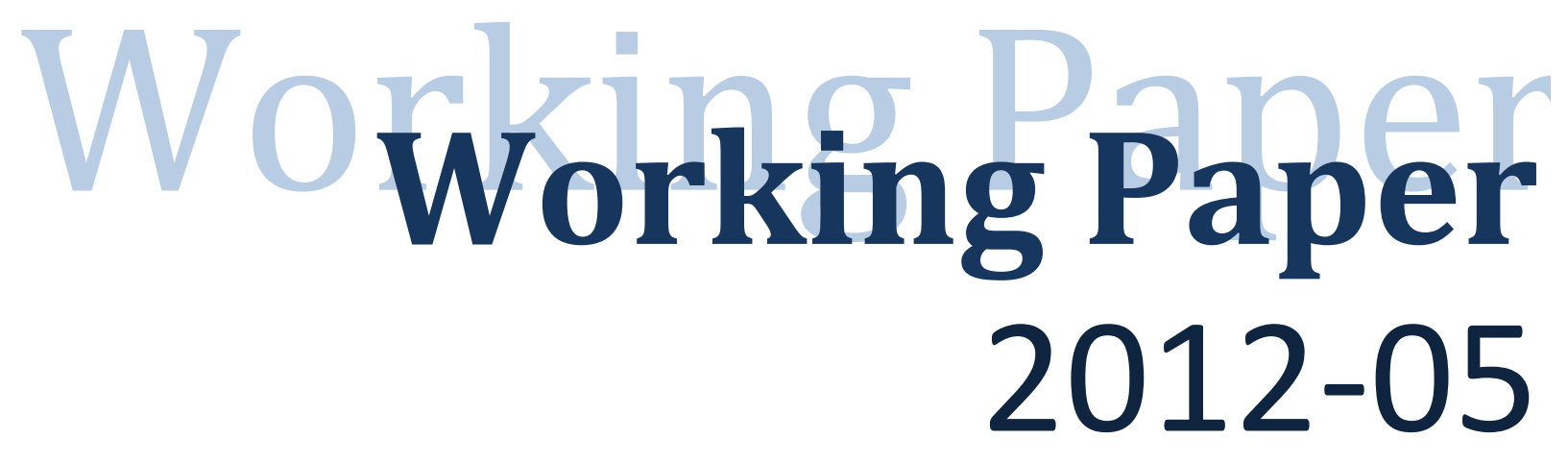

Why Do Large Firms Go For Islamic Loans?

Laurent Weill and Christophe J. Godlewski

April 2012 


\title{
Why Do Large Firms Go For Islamic Loans? ${ }^{+}$
}

\author{
Laurent Weill \\ University of Strasbourg and EM Strasbourg Business School \\ LARGE, 47 avenue de la Forêt Noire \\ 67000 Strasbourg, France \\ e-mail: laurent.weill@unistra.fr

\section{Christophe Godlewski} \\ University of Haute Alsace and EM Strasbourg Business School \\ LARGE, 61 avenue de la Forêt Noire \\ 67000 Strasbourg, France \\ e-mail: godlewski@em-strasbourg.eu
}

\footnotetext{
${ }^{+}$We would like to thank Hassan Aly and the seminar participants of the Middle East Economic Association Meeting in Denver (January 2012) for their helpful comments.
} 


\title{
Why Do Large Firms Go For Islamic Loans?
}

\begin{abstract}
$\underline{\text { Abstract }}$
This paper examines the motivations for large firms to choose an Islamic loan over a conventional loan and the recent expansion of Islamic finance activities. We employ a dataset of Islamic and conventional syndicated loans from countries in the Middle East and Southeast Asia for the period 2001-2009, testing determinants for the choice of an Islamic loan at the facility, firm, and country level. From the lenders standpoint, loan characteristics apparently do not influence the decision to offer Islamic loans, nor are they rationed to borrowers in terms of maturity or amount. Moreover, firms taking Islamic loans do not appear to differ in terms of default risk from firms taking conventional loans. We identify three country-level determinants as potential driving forces expanding the preference for Islamic loans. The strongest determinant is religiosity, i.e. the share of Muslim population in a country, but the quality of institutions and level of financial development also play substantial roles.
\end{abstract}

JEL Codes: G21, G32, O16.

Keywords: Islamic banks, loans. 


\section{Introduction}

There has been a huge expansion of Islamic financing activities over the past two decades. The Financial Times put the value of the industry globally at $\$ 1$ trillion in 2010 (Financial Times Special Report, 2010), up from \$140 billion in 1995 (Blominvest, 2009). These activities are of particular importance in the Middle East and Southeast Asia in countries with large Muslim populations. Despite considerable practitioner-generated material on Islamic financial products, however, the academic literature remains distinctly thin with regard to discussion on the causes and consequences of this phenomenon.

A number of studies analyze the differences in behavior between Islamic banks and conventional banks (e.g. Cihak and Hesse, 2010; Beck, Demirgüç-Kunt and Merrouche, 2010; Weill, 2011). Their main conclusion is that the expansion of Islamic banking is unlikely to have any major economic impact as differences in behavior from other banks are slight.

Even so, the dearth of literature on the emergence of Islamic finance is hard to explain, For example, the intuition that Islamic finance simply is an extension of religiosity does not consistently hold true. Multi-religion Malaysia hosts a vibrant Islamic finance industry, while 97 \% Islam Turkey has only seen Islamic banking develop on a limited scale so far.

One approach to gathering evidence on what might be driving lenders and borrowers to favor Islamic bank loans over conventional loans is to examine those areas where Islamic banking flourishes. Thus, we employ a dataset of syndicated loans containing Islamic and conventional loans from countries in the Middle East and Southeast Asia for the period 2001-2009.

A syndicated loan is a risk-spreading form of financing that requires at least two banks to grant funds jointly to a borrower. Focusing on syndicated loans has two advantages. First, information on single-issuer loans is hard to obtain and tends to be confined to studies using loan-level information for one country (e.g. Baele, Farooq, and Ongena, 2010, for Pakistan). In contrast, the data on syndicated loans are readily available and provide a basis for crosscountry analysis. Second, syndicated loans are typically granted to large companies. This allows us to focus on major corporate financial decisions.

We test three categories of determinants for the choice of an Islamic loan.

Under loan-specific determinants, we consider if banks show any differences in Islamic loan characteristics compared to conventional loans to check if these characteristics might influence the choice of a type of loan. It can indeed happen that borrowers are restricted in their choice of loan by the fact that banks are not willing to provide the similar loan in 
terms of maturity and amount if it is an Islamic or a conventional one. They can consider that the different nature of Islamic financings leads to a different default risk.

Under borrower-specific determinants, we focus on the financial condition of the borrower firm. Godlewski, Turk-Ariss, and Weill (2011) show that companies issuing sukuk were likelier to be in worse financial shape than firms issuing conventional bonds. We ask if the same distinction holds true for firms seeking bank debt financing. If borrowers with poorer financial status are resorting to Islamic financing, this should be reflected in lower loan quality of Islamic banks and hampered their expansion.

Under country-specific determinants, we look at the prevalence of Islamic religious practice in a country (religiosity), the quality of institutions, and levels of financial development and economic development. We want to check if the religious practice in Islam plays a significant role. Furthermore a key assumption is that better quality of institutions might favor the use of Islamic loans. Islamic loans are particularly dependent of the quality of institutions as their implementation involves more legal costs than conventional loans. As a consequence, the use of these loans should be favored by enhanced quality of institutions through better law enforcement or lower corruption that contribute to reduce legal costs.

This study hopefully offers insights in this interesting and evolving area of global finance. It may even be of use to authorities seeking to understand some of the factors that might lead large firms to choose Islamic loans over conventional loans.

The rest of the paper is organized as follows. Section 2 presents Islamic syndicated finance. Section 3 develops the tested determinants of the choice of an Islamic loan. Section 4 describes the data. The empirical results are reported in Section 5. We provide our concluding remarks in section 6 .

\section{Islamic syndicated finance}

This section first gives an overview of the principles and financing modes of Islamic finance, and then discusses some of the features of Islamic and conventional syndicated loans.

\subsection{Islamic finance: principles and financing modes}

Islamic finance can be defined as finance that conforms to Islamic law (Shariah) derived from the Qur'an and other sources. Among principles to be respected under Shariah is the famous 
prohibition against charging interest (riba). While there is a recurring debate on the interpretation of riba as to whether it is merely a prohibition on charging an excessive rate of interest or the charging of interest per se, the current consensus favors the wider interpretation of riba that includes all forms of interest. The fact that the provider of funds in a financial transaction is not allowed to charge interest does not mean that all forms of return are prohibited. Instead, interest is replaced by the concept of profit-and-losssharing. Under this view, both parties in a financial transaction are expected to share in the returns from a project. A related aspect of Islamic finance is the prohibition against contractual uncertainty (gharar). Contract terms must be clearly defined, explicit, and without ambiguity. The objective of this principle is to avoid the exploitation of one party by another in a transaction. Finally, Islamic finance cannot be used to finance sinful activities such as gambling or pig-farming.

Following the principles of prohibition on charging interest and profit-and-losssharing, Islamic finance has developed a number of specific financing products. Two core financing products are "partnership" products between the lender and the borrower based on the profit-and-loss-sharing principle: musharaka, and mudaraba. Under a mudaraba contract, the lender provides the capital and the borrower provides the effort and know-how. Profits are shared between both parties, while losses are borne solely by the lender. A musharaka contract is based on the sharing of profits between the lender and the borrower, and losses are shared as all parties have made capital contributions.

Two other widely used financing products are murabaha and ijara. Murabaha is essentially a mark-up sale; the lender buys the good and sells it to the customer in exchange of a price that includes the original cost and a specified margin. The price can be paid in several installments. While murabaha looks at first glance like a simple loan with interest, there are differences. The first is the absence of interest in the sense that the "return" applies to the sale of the good and not the sale of money (forbidden under Islamic law). The second is the prohibition against charging a penalty for default. The third concerns the fact that a risk is borne by the lender, as the lender owns the good for a specified period (even if this period can be considerably reduced to decrease risk).

Ijara is an Islamic form of leasing. The lender buys the good and leases it to the customer for a given period and a given rent. The bank does not make money from money in line with the prohibition against interest as it converts money into tangible assets to make the transaction. Here, there is no sharing of profits and losses; the lender knows the return of the project from the beginning of the transaction. However, the lender bears some risk as the lender is seen as owning the good throughout the contract period. 


\subsection{Islamic and conventional syndicated loans}

A syndicated loan is a loan where at least two banks jointly grant funds to the borrower. A lead bank develops a relationship with the borrower and negotiates the loan terms. The lead bank then looks for other banks to take part in the loan. The lead bank takes a fee for setting up each part of the deal. The final loan agreement specifies the size of the claim each member bank of the syndicate has on the debtor.

As observed by Godlewski and Weill (2008), banks may have several motivations for getting involved with the syndicated loan business. First, syndication allows the diversification of loan portfolios. Second, it avoids excessive single-name exposure (which may even be prohibited by banking regulations), while preserving a commercial relationship with the borrower. Third, such lending generates fee income for the lead bank. Fourth, it allows banks to fund loans in transactions where they lack origination capabilities.

The market of syndicated loans has skyrocketed over the past two decades. Using the Dealscan database, Godlewski and Weill (2008) calculate that the volume of syndicated loans expanded from US\$ 9.3 trillion in 1992 to US\$ 251 trillion in 2004. In the same period, the number of issues increased from 90 to 1,042. Syndicated loans today are a significant financing mode for companies.

Syndicated loans are of particular importance in emerging markets as they increase access to financing from an external source for large companies, and thus favor investment in these countries.

Islamic syndicated loans have many similarities with conventional syndicated loans. They are also provided by a syndicate of banks, and do not differ on the type of banks involved in the syndicate; i.e. Islamic loan syndicates do not exclude conventional banks. Indeed, a conventional bank could well be the lead bank for an Islamic syndicated loan. More generally, conventional banks can grant Islamic loans as long as they separate their Islamic financial activities from the rest of their activities.

Most of the differences between Islamic syndicated loans and conventional syndicated loans relate to the principles of Islamic finance. The return from an Islamic syndicated loan cannot be construed as interest, so the structure of these loans is mainly based on one of the four Islamic financing modes mentioned above. As pointed out by Iqbal (2007), an additional difference concerns the fact that the lead bank cannot sell the shares in the loan at a discount. 
They must be sold at par. The lead bank, however, may charge an administration fee for handling the syndication.

\section{Factors affecting the choice of an Islamic loan}

To investigate potential factors that might influence the decision by a bank to offer or a firm to choose a syndicated Islamic loan, we estimate a logit model in which the explained variable is a dummy variable equal to one if the syndicated loan is Islamic and zero else (Islamic). We distinguish whether the explaining variables of the model operate at the loan, firm or country level.

\subsection{Loan characteristics}

We test the role of several loan characteristics which might impact the choice of an Islamic loan. The key variables are loan size (Loan Amount), here defined as the log of the value of the loan in millions of US dollars, and maturity of the loan measured in years (Maturity).

Both variables can potentially provide information on financing constraints banks might associate with Islamic loans. A negative impact of one of these variables can be seen as a preference of the part of the bank to offer larger or longer-term conventional loans than their Islamic counterpart, which, in turn, could be seen as something problematic for banks regarding the Islamic loan format. Of course, bank reluctance to offer an Islamic loan at this point could be interpreted as banks associating greater default risk with Islamic loans, so they respond by limiting maturities and amounts of Islamic loans. The observation of smaller amount or shorter maturity for Islamic loans could then hamper the expansion of Islamic finance.

We include two control variables. First, we take into account the type of loan through a dummy variable equal to one if the loan is a term loan and zero otherwise (Loan Type). Any significant coefficient for Loan Type would suggest that borrowers choose an Islamic loan according to the type of loan. Second, we include the currency of denomination, with a dummy variable equal to one if the loan is denominated in US dollars (USD Currency).

\subsection{Firm characteristics}


We next include variables that reflect characteristics of the borrowing firm. As borrower information is scarce, we limit our choice of borrower characteristics to three variables.

The assumption we want to test here is whether firms in worse financial condition tend to prefer Islamic loans over conventional loans. In the case of direct financing, Godlewski, Turk-Ariss, and Weill (2011) show that firms in poor shape are more likely to issue sukuk than conventional bonds. They provide two explanations for this finding. First, as Islamic financial instruments are supposed to be based on profit-and-loss-sharing principles, borrowers with low return expectations have greater incentive to prefer Islamic financial instruments over conventional financial instruments. Indeed, borrowers expecting a high profit would be reluctant to share it and would prefer interest-based financing, whereas those expecting a low profit would go for profit-and-loss-sharing to minimize their potential losses. This adverse selection argument has been raised by Kuran (2004) to explain why Islamic banks do not supply more musharaka and mudaraba partnership financing. They have economic incentives to provide debt-based financing instruments like murabaha or ijara to avoid adverse selection only if they propose partnership financing. Second, the excess demand for sukuk bonds resulting from the combination of a strong demand for these instruments from Islamic banks with the limited supply of sukuk on the market makes the issuance of sukuk easier to sell than bonds issued via conventional banks. As a consequence, companies that are unable to issue a conventional bond due to their poor financial situation can still have access to financing through sukuk.

Thus, we ask if a borrowing firm in a weak financial condition that would resort to sukuk would also be inclined to seek an Islamic syndicated loan. This is a major concern for Islamic banks. If the financial condition of the pool of borrowers taking Islamic loans is poorer than borrowers taking conventional loans, Islamic banks may be setting themselves up for higher losses than conventional banks.

We consider two variables to take the financial situation of companies into account: indebtedness defined as the ratio of total debt to total assets (Debt to Assets), and profitability, which is measured by return on assets (ROA). If firms choosing Islamic loans are in worse financial shape than those opting for conventional loans, we should observe a negative coefficient for ROA and a positive coefficient for Debt to Assets.

Finally, we control for firm size to check if the size of the borrower plays a role on the choice of an Islamic loan. Firm size is measured by the log of total sales instead of the log of total assets to avoid any collinearity with the other two borrower characteristics (Firm Size). 


\subsection{Country characteristics}

We test the role of five country-specific determinants that could potentially influence the decision to choose an Islamic loan. For most determinants, we use a key variable and an alternative variable to test the sensitivity of our results.

The first determinant is quality of institutions. This is measured by the rule of law indicator provided by the World Bank database on Governance (Rule of Law). ${ }^{12}$ The indicator ranges from -2.5 to +2.5 with greater values associated with better quality of institutions. As explained by Kaufmann, Kraay, and Mastruzzi (2010), the indicator aims at "capturing perceptions of the extent to which agents have confidence in and abide by the rules of society, and in particular the quality of contract enforcement, property rights, the police, and the courts, as well as the likelihood of crime and violence." It is a composite indicator aggregating several indices, and thus not dependent of any one source. It provides an average opinion on the quality of institutions. This indicator is commonly used in academic studies to measure the quality of institutions (e.g. Dollar and Kraay, 2003). The alternative variable used to proxy quality of institutions is corruption. We utilize here another indicator from the World Bank database: the index of "Control of Corruption" (Control of Corruption), which also ranges from -2.5 to +2.5 with greater values for less corrupt countries.

A large strand of empirical literature links quality of institutions with bank behavior (e.g. Qian and Strahan, 2007; Bae and Goyal, 2009). We thus expect higher quality of institutions to have a positive influence on the choice of an Islamic loan. Indeed, Islamic financial instruments should be particularly dependent of the quality of institutions as their implementation implies more legal arrangements than conventional financial instruments. As pointed out by Visser (2009), the most widespread tool in Islamic finance is murabaha, which involves two sales transactions instead of one. Partnership financings using musharaka or mudaraba formats also require the establishment of separate legal entities. As a consequence, Islamic finance typically entails more legal costs than conventional financing arrangements and thus is more dependent of the quality of institutions. Better quality of institutions through tougher law enforcement or weaker corruption in turn reduces legal costs. For instance, a lack of good law enforcement forces banks to take greater care in designing loan contracts, which results in additional costs. The improvement of quality of institutions thus favors the choice of

\footnotetext{
${ }^{1}$ Available at www.govindicators.org

${ }^{2}$ Data for the rule of law indicator are available for all years with the exception of 2001 . For 2001, we perform a linear interpolation between values for 2000 and 2002.
} 
an Islamic loan by reducing the costs associated to these loans in excess relative to conventional loans related to the greater legal costs.

Our second determinant is religiosity. We consider the fraction of adherents to Muslim religion (Muslim) in the national population. Data come from CIA World Factbook. The alternative variable here is the fraction of adherents to Muslim religion in 2000 (Muslim2) from the dataset "Religion Adherence Indicators" on Robert Barro's website. ${ }^{3}$ We expect a positive impact of this variable on the choice of an Islamic loan. This intuitive hypothesis is based on the religious motives to choose this source of financing. This view finds support in the results of Baele, Farooq, and Ongena (2010) on the link between religious belief and borrower behavior. These authors compare default rates on Islamic and conventional loans for business loans in Pakistan, and find that default rates are much lower for Islamic loans. They interpret this finding as evidence that borrowers using Islamic loans face a moral conflict with their religious beliefs if they default on an Islamic loan. Nonetheless, the fact that governmental support can play a significant role on the use of Islamic finance might counterbalance this view. Malaysia is a well-known case here. This country is considered the global hub of Islamic finance, owing to its dominant position in the sukuk business. Yet Malaysia's share of Muslims in the population is only slightly above $50 \%$.

The third determinant is financial development. The adopted measure for our study is the ratio of volume of credit to private enterprises to GDP (Private Credit), which is commonly used in the empirical literature to measure financial development (e.g. Levine, Loayza, and Beck, 2000; Djankov, McLiesh, and Shleifer, 2007). This ratio measures the extent to which credit is allocated to private firms as opposed to government or state-owned firms. It measures the size of the financial sector, and isolates credit issued to the private sector. Yearly data come from the Financial Structure Dataset by Beck and Demirgüç-Kunt (2009). Alternatively, we use the ratio of liquid liabilities to GDP (Liquid Liabilities), another commonly used measure of financial development.

Our assumption here is that financial development favors the choice of an Islamic loan. As mentioned, Islamic financial products are more complex than conventional financial products, and this is especially true for large non-standardized Islamic financing deals. As a consequence, a low degree of financial literacy of economic agents can present an obstacle to

\footnotetext{
${ }^{3}$ We have also tested the use of the fraction of adherents to Muslim religion in 1900 (which is included in this dataset). Gokcekus (2008) shows that the percentage of Protestants in 1900 has a greater impact on current corruption than the percentage of Protestants in 2000 as religion can influence economic outcome through tradition more than current practice. Thus, we similarly check to see of religious practice 100 years ago plays a greater role than current religious practice. The results were totally similar.
} 
the use of Islamic financial products. As financial literacy is "the ability to process financial information and make informed decisions about personal finance" (Cole and Fernando, 2008), we assume Islamic finance requires a greater financial literacy than conventional finance. Consequently, greater financial literacy should enhance demand for Islamic financial products. In line with this argument, the surveys in India and Indonesia of Cole, Sampson, and $\mathrm{Zia}$ (2011) suggest that financial literacy influences economic behavior of economic agents by making them better at risk management.

Thus, we infer that greater financial development contributes to enhance financial literacy of economic agents by familiarizing them with the use of financial products. Such financial sophistication facilitates the choice of an Islamic loan relative to a conventional loan.

Our fourth determinant is economic output as measured by GDP per capita. It is defined as the logarithm of GDP per capita in purchasing power parity with yearly data coming from World Bank's World Development Indicators (GDP per capita). We expect a positive role of economic development on the choice of an Islamic loan. It is also related to the greater costs of Islamic finance. Some scholars have argued that Islamic financial products are more expensive than conventional financial products. El-Gamal (2007) mentions that some observers of the Islamic banking industry refer to the additional charges and rates of Islamic banks as "the cost of being Muslim." This view is supported by the observation of lower cost efficiency for Islamic banks relative to conventional banks (Abdul-Majid, Saal, and Battisti, 2010; Srairi, 2010). Thus, higher economic output could favor higher use of Islamic finance as people with more income have easier access to costly financial products. In microeconomic terms, Islamic financial products here might be viewed as a luxury good.

The fifth determinant is bank cost. Following Barth et al. (2004), this is defined as the ratio of overhead costs to total banking assets (Overheads). Our alternative measure for bank cost is the cost-to-income ratio (Cost to Income), defined as total cost to total income of banks. Yearly data come from the Financial Structure Dataset. Our prediction is a negative influence of bank cost on the choice of an Islamic loan. This assumption is again based on the observation that Islamic financial products can be expected to be more costly to produce than conventional financial products as they are more complex and entail higher legal costs. This gap in cost against Islamic financial products might be exacerbated in banking industries with greater costs. Thus, greater bank cost would favor the choice of a conventional loan by contributing to enhance the gap in pricing between both types of loans. 


\section{Data}

Our information on loans and borrowers was taken from the Bloomberg Terminal Server and spans the period 2001-2009. We consider seven countries in the Middle East and Southeast Asia: Bahrain, Indonesia, Kuwait, Malaysia, Qatar, Saudi Arabia, and the United Arab Emirates.

The size of the sample is determined by information availability on the variables used in the estimations. Sample size is especially limited by the unavailability of information on borrower characteristics. Nevertheless, we obtain a sample of 231 loan facilities made to 138 borrowers.

Table 1 lists descriptive statistics for the variables. We observe that $19.5 \%$ of loans are Islamic and the mean loan amount is US\$ 7.88 billion (in accordance with the expectation that syndicated loans tend to be large loans). The loan maturity is 7.8 years on average. Borrowers are large firms with mean net sales of US\$ 2.03 billion. They carry relatively little debt with debt-to-total-assets ratios averaging $32.8 \%$. They also tend to be very profitable with a mean ratio of net income to total assets of $20.2 \%$.

Table 2 provides a first glance on the possible determinants of the choice of an Islamic loan by comparing means by type of loan. On average, Islamic loans tend to be smaller (US\$ 0.91 versus $\$ 8.16$ billion) and carry shorter maturities (7.2 years versus 8.8 years) than conventional loans. This suggests that the choice of an Islamic loan is constrained by the characteristics of the loan. Borrowers looking for bigger loans or loans with longer maturities could be forced to go for a conventional loan. On average, firms taking conventional loans are larger (annual net sales of US\$ 1.86 billion versus US\$ 0.72 billion) and have higher profitability $(25.4 \%$ versus $-0.05 \%)$ than those taking Islamic loans. However, there is no significant difference in indebtedness ratios between firms talking conventional and Islamic loans.

At the country level, we note that Islamic loans are chosen in countries where the practice of Islam is widespread (87.9\% versus $82.8 \%$ for Muslim), where the quality of institutions is better ( 0.41 versus 0.15 for Rule of Law), where financial development is more advanced (58.1\% versus $51.2 \%$ for Private Credit), and where economic output is higher (US\$ 25,700 versus US\$ 18,200 for GDP per Capita). Thus, country-level variables apparently do influence the decision to take an Islamic loan. 
All in all, this preliminary comparison suggests some determinants play a role in the choice of an Islamic loan at the loan, firm, and country level.

Additionally, Table 3 provides information on country and year of loans. It is of interest to observe that the two Southeast Asian countries represent $65.8 \%$ of the total number of the loans in our sample. This is in line with the importance of Islamic finance activities in that region of the world.

\section{Results}

This section presents our results on factors that might influence the decision to choose an Islamic loan. We perform several logit regressions with various sets of tested factors. In Table 4, the first model considers only loan characteristics (column 1). The second model adds in borrower characteristics (column 2). The third adds in country-level variables (column 3), so the third specification can be considered as the key specification that includes all tested explaining variables. Table 5 proposes four estimations in which we replace one-by-one each country-level variable with its alternative variable. These estimations allow testing the robustness of our results. We respectively replace the variables for religiosity (replacing Muslim with Muslim2 in column 1), financial development (Private Credit with Liquid Liabilities in column 2), bank cost (Overheads with Cost to Income in column 3), and quality of institutions (Rule of Law with Control of Corruption in column 4). Four overarching conclusions emerge.

First, we find no impact of loan characteristics on the choice of an Islamic loan relative to a conventional loan. Loan Amount is not significant in all estimations, showing there is no link between the size of the loan and choosing an Islamic loan. This finding is of interest as it suggests that firms looking for a large loan are not constrained to the use of conventional loans. Maturity is also not significant in most estimations. We observe a significantly negative coefficient only in two robustness checks. This suggests that maturity does not also play a role for the choice of an Islamic loan.

The conclusion that loan characteristics do not drive the choice of loan suggests that borrowers lack particular incentives to ask for an Islamic loan when looking for a loan with a specific maturity or amount. Furthermore, it tends to show that banks do not associate Islamic loans with greater default risk (which might well have been the case, given the profit-andloss-sharing principles of Islamic finance) as banks would have been less reluctant to get 
involved in a conventional loan than a syndicated loan when the requested facility has a longer maturity or larger amount.

Second, we observe no link between the financial condition of the borrower and the choice of loan when analyzing firm characteristics. Debt to Assets and ROA are not significant in most estimations, meaning that indebtedness and profitability do not exert a role on the choice of an Islamic loan relative to a conventional loan. This finding is of major interest for Islamic finance as there is no indication that firms taking Islamic loans are in worse financial condition than conventional loan takers. This somewhat contradicts the earlier observation of Godlewski, Turk-Ariss, and Weill (2011) that issuers of sukuk tended to be in worse financial shape than issuers of conventional bonds, but is good news for development of Islamic finance generally - Islamic syndicated loans are not associated on average with riskier borrowers than those taking conventional syndicated loans. As a final note, Firm Size is significantly negative in all estimations, i.e. larger firms are less likely to choose an Islamic loan.

Third, our study of country-level variables shows the significant role of religiosity, and to a lesser extent, impacts from quality of institutions and financial development on the choice of an Islamic loan.

The effect of religiosity is consistent with expectations: we observe a positive and significant influence of Muslim and the alternative variable Muslim2 in all estimations. This finding corroborates the view that greater religious practice of Islam contributes to enhance the likelihood to choose an Islamic loan. Religious motives matter for the choice of an Islamic loan. Even if this conclusion might look obvious, we must stress that few empirical works show it and that the empirical observation of the development of Islamic finance across countries definitely suggests qualifying this intuitive view.

We find mixed evidence for the role of quality of institutions. Our main measure of quality of institutions, Rule of Law, is positive in all estimations, but only significant in the main specification and one robustness check out of a total of four. Moreover, the alternative variable for quality of institutions, Control of Corruption, is not significant. Thus, these results provide limited support for the fact that greater quality of institutions goes along with higher use of Islamic loans. We interpret this finding as evidence that Islamic financial instruments require more legal arrangements and greater trust in partnership arrangements than conventional financial products. All other things equal, better law enforcement favors the use of an Islamic loan. 
Similarly, we find some support for the influence of financial development. The coefficient of Private Credit is positive in all estimations and significant in two robustness checks, while the alternative variable for financial development, Liquid Liabilities, is significantly positive. This suggests that enhanced financial development contributes to favor the use of Islamic loans.

Finally, the level of bank cost and economic development does not seem to exert an influence on the choice of an Islamic loan. Both variables for bank costs (Overheads and Cost to Income) and Economic Development are not significant in most estimations. Both are only significantly negative in the robustness check performed with the alternative measure for religiosity. These findings are of interest owing to their implications: they suggest that positive economic changes through lower bank costs or greater economic development do not influence the use of Islamic financing.

It must be stressed that the lack of significance for variables controlling for bank cost does not mean that bank cost does not matter for Islamic finance. Several studies have shown the existence of a gap in cost efficiency between Islamic banks and conventional banks (Abdul-Majid, Saal, and Battisti, 2010; Srairi, 2010). This gap can influence the expansion of Islamic finance as lower cost performance for Islamic banks might hamper this trend. Nonetheless, we consider the level of bank cost as a whole in a country without differentiating Islamic and conventional banks as both types of banks may get involved in Islamic syndicated loans. Our result stresses only the fact that the average level of bank cost in a country does not matter.

\section{Concluding remarks}

This paper contributes to understanding of the factors behind the expansion of Islamic finance. Our investigation into what might lead a large firm to prefer a syndicated Islamic loan over a conventional syndicated loan produced three main findings.

First, loan characteristics do not appear to influence the choice of an Islamic loan. We observe no links between the amount and maturity of the loan in determining the choice of borrowing firms. This indicates borrowers applying for an Islamic loan are not rationed in terms of maturity or amount. It suggests that Islamic loans are not associated to greater default risk by lenders.

Second, the quality of the borrower does not influence the choice of an Islamic loan. 
This finding is of importance as firms in weaker financial condition have displayed a preference for issuing sukuk over conventional bonds (Godlewski, Turk-Ariss, and Weill, 2011). Nevertheless, this finding does not hold in the case of syndicated loan-taking. Thus, banks providing Islamic syndicated loans are not subject to adverse selection from attracting riskier borrowers, a finding that has major implications for the development of Islamic finance.

Third, we find evidence for three country-level factors influencing the choice of a syndicated Islamic loan. The largest role is played by religiosity, but this is also accompanied to a lesser extent by the potential influences of quality of institutions and financial development. The role of religiosity coincides with the intuition that the larger the share of Muslim population in a country increases the likelihood firms will seek an Islamic loan. We also show that enhanced quality of institutions and increased financial development favor the choice of an Islamic loan. These conclusions have major implications for the future of Islamic finance in both MENA countries and Western countries.

The recent changes brought about by the Arab Spring may well enhance the quality of institutions in affected Arab countries as corruption and weak governance have been key sources of frustration underlying the changes. If changes bring about improvements in law enforcement and lower corruption, the resulting improvements in the legal environment should be more conducive to the use of Islamic loans.

Finally, these factors suggest we can expect an expansion of Islamic financing in Western countries with substantial Muslim populations. These countries typically have much better quality of institutions and more sophisticated financial systems than are found in most of the countries in Middle East and Southeast Asia considered in our analysis. As religiosity is a driving factor, we could see the emergence of Islamic finance in a number of Western countries as well. 


\section{References}

Abdul-Majid, M., D. Saal, and G. Battisti, 2010. Efficiency in Islamic and Conventional Banking: An International Comparison. Journal of Productivity Analysis 34, 25-43.

Bae, K., and V. Goyal, 2009. Creditor Rights, Enforcement and Bank Loans. Journal of Finance 64, 2, 823-860.

Baele, F., M. Farooq, and S. Ongena, 2010. Of Religion and Redemption: Evidence from Default on Islamic Loans. Tilburg University.

Barth, J., G. Caprio, and R. Levine, 2004. Bank Regulation and Supervision: What Works Best? A New Database on Financial Development and Structure. Journal of Financial Intermediation 13, 205-248.

Beck, T., and A. Demirgüç-Kunt, 2009. Financial Institutions and Markets across Countries and over Time: Data and Analysis, World Bank Policy Research Working Paper 4943, May 2009.

Beck, T., A. Demirgüç-Kunt, and O. Merrouche, 2010. Islamic vs. Conventional Banking: Business Model, Efficiency and Stability. World Bank Policy Research Paper n5446, World Bank.

Blominvest, 2009. Islamic Banking in the MENA Region. Blominvest Bank, February.

Cihak, M., and H. Hesse, 2010. Islamic Banks and Financial Stability: An Empirical Analysis. Journal of Financial Services Research 38, 95-113.

Cole, S., and N. Fernando, 2008. Assessing the Importance of Financial Literacy. Asian Development Bank.

Cole, S., T. Sampson, and B. Zia, 2011. Prices or Knowledge? What Drives Demand for Financial Services in Emerging Markets? Journal of Finance 66, 6, 1933-1967.

Djankov, S., C. McLiesh, and A. Shleifer, 2007. Private Credit in 129 Countries, Journal of Financial Economics 84, 2, 299-329.

Dollar, D., and A. Kraay, 2003. Institutions, Trade and Growth. Journal of Monetary Economics 50, 1, 133-162.

El-Gamal, M., 2007. Incoherence of Contract-Based Islamic Financial Jurisprudence in the Age of Financial Engineering. Rice University.

Godlewski, C., R. Turk-Ariss, and L. Weill, 2011. Do Markets Perceive Sukuk and Conventional Bonds as Different Financing Instruments? BOFIT Discussion Paper 6/2011, Bank of Finland.

Godlewski, C., and L. Weill, 2008. Syndicated Loans in Emerging Markets. Emerging Markets Review, 9, 206-219.

Gokcekus, O., 2008. Is It Protestant Tradition or Current Protestant Population that Affects Corruption? Economics Letters 99, 1, 59-62.

Iqbal, A., 2007. Syndicated Islamic Finance. Islamic Finance News, 2 November 2007.

Kaufmann, D., A. Kraay, and M. Mastruzzi, 2010. The Worldwide Governance Indicators: A Summary of Methodology, Data and Analytical Issues. World Bank Policy Research Working Paper No. 5430, World Bank.

Kuran, T. 2004. Islam and Mammon, Princeton University Press.

Levine R., Loayza, N., and T. Beck, 2000. Financial Intermediation and Growth: Causality and Causes, Journal of Monetary Economics 46, 31-77.

Qian, J. and P. Strahan, 2007. How Laws \& Institutions Shape Financial Contracts: The Case of Bank Loans, Journal of Finance 62, 6, 2803-2834.

Srairi, S.A., 2010. Cost and Profit Efficiency of Conventional and Islamic Banks in GCC Countries. Journal of Productivity Analysis 34, 45-62.

Visser, H., 2009. Islamic Finance: Principles and Practice. Edward Elgar. 
Weill, L., 2011. Do Islamic Banks Have Greater Market Power? Comparative Economic Studies 53, 679-693. 
Table 1.

Variables and Summary Statistics

Means and standard deviations for variables used in subsequent estimations. Source: Bloomberg database, unless other indicated. $\mathrm{N}=231$.

\begin{tabular}{|c|c|c|c|}
\hline Variable & Description & Mean & $\begin{array}{l}\text { Std. } \\
\text { Dev. }\end{array}$ \\
\hline Islamic & $\begin{array}{l}\text { Dummy variable equal to one if the loan } \\
\text { is Islamic. }\end{array}$ & 0.195 & 0.397 \\
\hline Loan Amount & $\begin{array}{l}\text { Logarithm of the size of the loan in } \\
\text { million US dollars }\end{array}$ & 9.897 & 10.978 \\
\hline Maturity & Maturity of the loan in years & 7.784 & 7.604 \\
\hline Term Loan & $\begin{array}{l}\text { Dummy variable equal to one if the loan } \\
\text { is a term loan }\end{array}$ & 0.771 & 0.421 \\
\hline USD Currency & $\begin{array}{l}\text { Dummy variable equal to one if the loan } \\
\text { is denominated in US dollars }\end{array}$ & 0.654 & 0.477 \\
\hline Firm Size & Logarithm of sales in million US dollars & 9.307 & 9.740 \\
\hline Debt to Assets & Total debt to total assets & 0.328 & 0.187 \\
\hline ROA & Net income to total assets & 0.202 & 1.140 \\
\hline GDP per Capita & $\begin{array}{l}\text { Logarithm of GDP per capita at PPP. } \\
\text { Source: World Bank World } \\
\text { Development Indicators. }\end{array}$ & 4.147 & 4.265 \\
\hline Muslim & $\begin{array}{l}\text { Fraction of adherents to Muslim } \\
\text { religion. Source: CIA World Factbook }\end{array}$ & 0.802 & 0.135 \\
\hline Muslim2 & $\begin{array}{l}\text { Fraction of adherents to Muslim religion } \\
\text { in } 2000 \text {. Source: Robert Barro's dataset } \\
\text { "Religion adherence indicators" }\end{array}$ & 0.639 & 0.174 \\
\hline Private Credit & $\begin{array}{l}\text { Ratio of the volume of credit to private } \\
\text { companies to GDP. Source: Financial } \\
\text { Structure Dataset. }\end{array}$ & 0.533 & 0.311 \\
\hline Liquid Liabilities & $\begin{array}{l}\text { Liquid liabilities to GDP. Source: } \\
\text { Financial Structure Dataset. }\end{array}$ & 0.652 & 0.321 \\
\hline Overheads & $\begin{array}{l}\text { Overhead costs to total assets. Source: } \\
\text { Financial Structure Dataset. }\end{array}$ & 0.022 & 0.007 \\
\hline Cost to Income & $\begin{array}{l}\text { Total costs to total assets. Source: } \\
\text { Financial Structure Dataset. }\end{array}$ & 0.449 & 0.074 \\
\hline Rule of Law & $\begin{array}{l}\text { Rule of law indicator which ranges } \\
\text { from }-2.5 \text { to (low law enforcement) } \\
+2.5 \text { (high law enforcement). Source: } \\
\text { World Bank. }\end{array}$ & 0.073 & 0.559 \\
\hline $\begin{array}{l}\text { Control of } \\
\text { Corruption }\end{array}$ & $\begin{array}{l}\text { Control of Corruption indicator } \\
\text { which ranges from }-2.5 \text { (high } \\
\text { corruption) to }+2.5 \text { (low corruption). } \\
\text { Source: World Bank }\end{array}$ & -0.084 & 0.522 \\
\hline
\end{tabular}


Table 2.

Means by type of loans

This table provides means for variables used in subsequent estimations by type of loans. Mean t-test or chi ${ }^{2}$ test is included.

\begin{tabular}{|c|c|c|c|}
\hline Variable & $\begin{array}{c}\text { Islamic } \\
\text { loans }\end{array}$ & $\begin{array}{c}\text { Conventional } \\
\text { loans }\end{array}$ & $\begin{array}{c}\text { Mean t-test or } \\
\text { chi }^{2} \text { test }\end{array}$ \\
\hline Loan Amount & 905.310 & $8,163.100$ & $2.27 * *$ \\
\hline Maturity & 7.157 & 8.752 & $3.06^{* * *}$ \\
\hline Term Loan & 0.629 & 0.837 & $46.87 * * *$ \\
\hline USD Currency & 0.669 & 0.716 & 1.93 \\
\hline Firm Size & 724.44 & 1857.70 & $2.48 * *$ \\
\hline Debt to Assets & 0.357 & 0.342 & -0.51 \\
\hline ROA & -0.051 & 0.254 & $2.57 * *$ \\
\hline GDP Per Capita & $25,670.400$ & $18,152.700$ & $-5.74 * * *$ \\
\hline Muslim & 0.879 & 0.828 & $-5.29 * * *$ \\
\hline Muslim2 & 0.754 & 0.656 & $-8.58 * * *$ \\
\hline Private Credit & 0.581 & 0.512 & $-2.74 * * *$ \\
\hline Liquid Liabilities & 0.665 & 0.633 & -1.21 \\
\hline Overheads & 0.018 & 0.020 & $5.07 * * *$ \\
\hline Cost to Income & 0.369 & 0.416 & $6.40 * * *$ \\
\hline Rule of Law & 0.405 & 0.154 & $-8.40 * * *$ \\
\hline Control of Corruption & 0.496 & 0.179 & $-6.96 * * *$ \\
\hline
\end{tabular}


Table 3.

Sample by country and by year

Table reports the breakdown of our sample by country and by year.

\begin{tabular}{lccc}
\hline Country & Percentage & Year & Percentage \\
\hline Bahrain & 5.19 & 2001 & 0.43 \\
Indonesia & 38.53 & 2002 & 2.16 \\
Kuwait & 9.52 & 2003 & 0 \\
Malaysia & 27.27 & 2004 & 0 \\
Qatar & 5.19 & 2005 & 3.90 \\
Saudi Arabia & 14.29 & 2006 & 9.52 \\
& & 2007 & 17.75 \\
& & 2008 & 33.33 \\
& & 2009 & 32.90 \\
\hline
\end{tabular}


Table 4.

Main estimations

Logit regressions. The dependent variable is Islamic. Definitions of variables appear in Table 1. Table reports coefficients with standard deviations in parentheses. $*, * *, * * *$ denote an estimate significantly different from 0 at the $10 \%, 5 \%$ or $1 \%$ level. Dummy variables for year and industry are included in the regressions, but not reported here.

\begin{tabular}{|c|c|c|c|}
\hline \multirow[b]{2}{*}{ Explanatory variables } & \multicolumn{3}{|c|}{ Estimations } \\
\hline & $(1)$ & $(2)$ & (3) \\
\hline Loan Amount & $\begin{array}{l}0.099 \\
(0.10)\end{array}$ & $\begin{array}{l}0.117 \\
(0.10)\end{array}$ & $\begin{array}{l}-0.351 \\
(0.23)\end{array}$ \\
\hline Maturity & $\begin{array}{r}-0.017 \\
(0.02)\end{array}$ & $\begin{array}{r}-0.006 \\
(0.03)\end{array}$ & $\begin{array}{r}-0.079 \\
(0.06)\end{array}$ \\
\hline Term Loan & $\begin{array}{c}-0.959 * * \\
(0.43)\end{array}$ & $\begin{array}{c}-1.086^{* *} \\
(0.45)\end{array}$ & $\begin{array}{c}-1.444^{* *} \\
(0.74)\end{array}$ \\
\hline USD Currency & $\begin{array}{r}-0.391 \\
(0.55)\end{array}$ & $\begin{array}{r}-0.436 \\
(0.73)\end{array}$ & $\begin{array}{r}-0.541 \\
(0.90)\end{array}$ \\
\hline Firm Size & - & $\begin{array}{l}-0.004 \\
(0.10)\end{array}$ & $\begin{array}{c}-0.292^{* *} \\
(0.13)\end{array}$ \\
\hline ROA & - & $\begin{array}{l}-1.793 \\
(1.39)\end{array}$ & $\begin{array}{r}-1.425 \\
(1.23)\end{array}$ \\
\hline Debt to Assets & - & $\begin{array}{l}0.018 \\
(1.07)\end{array}$ & $\begin{array}{r}1.994 \\
(1.32)\end{array}$ \\
\hline Muslim & - & - & $\begin{array}{c}30.236^{* * *} \\
(9.71)\end{array}$ \\
\hline Private Credit & - & - & $\begin{array}{l}5.122 \\
(3.15)\end{array}$ \\
\hline Overheads & - & - & $\begin{array}{c}-34.076 \\
(57.03)\end{array}$ \\
\hline Rule of Law & - & - & $\begin{array}{c}8.621 * * \\
(4.31)\end{array}$ \\
\hline GDP per Capita & - & - & $\begin{array}{r}-1.989 \\
(1.53)\end{array}$ \\
\hline Intercept & $\begin{array}{c}-16.169 * * * \\
(2.21)\end{array}$ & $\begin{array}{c}-16.376^{* * *} \\
(3.07)\end{array}$ & $\begin{array}{c}-15.356 \\
(9.96)\end{array}$ \\
\hline Number of observations & 231 & 231 & 231 \\
\hline Number of borrowers & 138 & 138 & 138 \\
\hline Log likelihood & -100.640 & -96.971 & -65.056 \\
\hline Pseudo- $\mathrm{R}^{2}$ & 0.1165 & 0.1487 & 0.4289 \\
\hline
\end{tabular}


Table 5.

Robustness checks

Logit regressions. The dependent variable is Islamic. Definitions of variables appear in Table 1. Table reports coefficients with standard deviations in parentheses. $*, * *, * * *$ denote an estimate significantly different from 0 at the $10 \%, 5 \%$ or $1 \%$ level. Dummy variables for year and industry are included in the regressions, but not reported here.

\begin{tabular}{|c|c|c|c|c|}
\hline \multirow[b]{2}{*}{ Explanatory variables } & \multicolumn{4}{|c|}{ Estimations } \\
\hline & $(1)$ & $(2)$ & $(3)$ & (4) \\
\hline Loan Amount & $\begin{array}{c}-0.423 \\
(0.26)\end{array}$ & $\begin{array}{l}-0.356 \\
(0.22)\end{array}$ & $\begin{array}{l}-0.349 \\
(0.23)\end{array}$ & $\begin{array}{l}-0.200 \\
(0.17)\end{array}$ \\
\hline Maturity & $\begin{array}{c}-0.150^{* *} \\
(0.07)\end{array}$ & $\begin{array}{c}-0.120 * \\
(0.07)\end{array}$ & $\begin{array}{l}-0.060 \\
(0.06)\end{array}$ & $\begin{array}{l}-0.018 \\
(0.04)\end{array}$ \\
\hline Term Loan & $\begin{array}{c}-1.560 * * \\
(0.79)\end{array}$ & $\begin{array}{c}-1.376^{*} \\
(0.72)\end{array}$ & $\begin{array}{c}-1.401^{* *} \\
(0.70)\end{array}$ & $\begin{array}{c}-1.801^{* *} \\
(0.83)\end{array}$ \\
\hline USD Currency & $\begin{array}{r}-0.303 \\
(0.85)\end{array}$ & $\begin{array}{r}-0.242 \\
(0.94)\end{array}$ & $\begin{array}{r}-0.681 \\
(1.04)\end{array}$ & $\begin{array}{r}-0.706 \\
(0.90)\end{array}$ \\
\hline Firm Size & $\begin{array}{c}-0.372 * * * \\
(0.14)\end{array}$ & $\begin{array}{c}-0.347 * * \\
(0.14)\end{array}$ & $\begin{array}{c}-0.264^{*} \\
(0.15)\end{array}$ & $\begin{array}{l}-0.220 \\
(0.14)\end{array}$ \\
\hline ROA & $\begin{array}{r}-1.339 \\
(0.87)\end{array}$ & $\begin{array}{c}-1.242 * * \\
(0.60)\end{array}$ & $\begin{array}{l}-1.683 \\
(1.69)\end{array}$ & $\begin{array}{l}-1.756 \\
(1.28)\end{array}$ \\
\hline Debt to Assets & $\begin{array}{c}2.677^{*} \\
(1.53)\end{array}$ & $\begin{array}{l}1.353 \\
(1.34)\end{array}$ & $\begin{array}{l}2.213 \\
(1.59)\end{array}$ & $\begin{array}{r}1.940 \\
(1.29)\end{array}$ \\
\hline Muslim & - & $\begin{array}{c}29.767 * * * \\
(9.59)\end{array}$ & $\begin{array}{c}29.446^{* * *} * \\
(9.94)\end{array}$ & $\begin{array}{c}15.142 * * * \\
(5.86)\end{array}$ \\
\hline Muslim2 & $\begin{array}{c}28.495 * * * \\
(7.65)\end{array}$ & - & - & - \\
\hline Private Credit & $\begin{array}{c}7.377 * * \\
(3.13)\end{array}$ & - & $\begin{array}{l}4.572 \\
(3.65)\end{array}$ & $\begin{array}{c}8.117 * * * \\
(2.67)\end{array}$ \\
\hline Liquid Liabilities & - & $\begin{array}{l}9.680^{*} \\
(5.58)\end{array}$ & - & - \\
\hline Overheads & $\begin{array}{c}-120.274^{*} \\
(62.51)\end{array}$ & $\begin{array}{l}26.548 \\
(67.55)\end{array}$ & - & $\begin{array}{c}-42.699 \\
(58.79)\end{array}$ \\
\hline Cost to Income & - & - & $\begin{array}{c}-2.381 \\
(6.60)\end{array}$ & - \\
\hline Rule of Law & $\begin{array}{l}2.852 \\
(3.17)\end{array}$ & $\begin{array}{l}3.827 \\
(5.75)\end{array}$ & $\begin{array}{c}8.930 * * \\
(4.27)\end{array}$ & - \\
\hline Control of Corruption & - & - & - & $\begin{array}{l}-1.728 \\
(2.30)\end{array}$ \\
\hline GDP per Capita & $\begin{array}{c}-2.744^{*} \\
(1.51)\end{array}$ & $\begin{array}{l}0.227 \\
(2.13)\end{array}$ & $\begin{array}{l}-2.071 \\
(1.51)\end{array}$ & $\begin{array}{l}1.416 \\
(1.09)\end{array}$ \\
\hline Intercept & $\begin{array}{c}-1.631 \\
(12.94)\end{array}$ & $\begin{array}{c}-35.268^{* *} \\
(17.98)\end{array}$ & $\begin{array}{r}-15.072 \\
(11.09)\end{array}$ & $\begin{array}{c}-36.529 * * * \\
(8.44)\end{array}$ \\
\hline Number of observations & 231 & 231 & 231 & 231 \\
\hline Number of borrowers & 138 & 138 & 138 & 138 \\
\hline Log likelihood & -60.466 & -64.578 & -65.156 & -67.620 \\
\hline Pseudo- $\mathrm{R}^{2}$ & 0.4692 & 0.4331 & 0.4280 & 0.4064 \\
\hline
\end{tabular}


IARGE

\section{Working Papers}

\section{Laboratoire de Recherche en Gestion \& Economie}

http://ifs.u-strasbg.fr/large/publications/publications.htm

Université de Strasbourg

Pôle Européen de Gestion et d'Economie

61 avenue de la Forêt Noire

67085 Strasbourg Cedex

http://ifs.unistra.fr/large 